\title{
PENGARUH KONDISI pH TERHADAP RESPONS FISIOLOGIS DAUN LAMUN JENIS Cymodocea rotundata
}

\section{THE EFFECT OF PH CONDITIONS ON PHYSIOLOGICAL RESPONSE OF SEAGRASS LEAVES Cymodocea rotundata}

\author{
Yudho Andika $^{1 *}$, Mujizat Kawaroe ${ }^{2}$, Hefni Effendi $^{3}$, \& Neviaty P. Zamani ${ }^{2}$ \\ ${ }^{1}$ Program Studi Ilmu Kelautan, Sekolah Pascasarjana, IPB Univeristy, Bogor, 16680, Indonesia \\ ${ }^{2}$ Departemen Ilmu dan Teknologi Kelautan, FPIK, IPB University, Bogor, 16680, Indonesia \\ ${ }^{3}$ Departemen Manajemen Sumberdaya Perairan, FPIK, IPB Univeristy, Bogor, 16680, Indonesia \\ *E-mail: andikayudho43@gmail.com
}

\begin{abstract}
Increased carbon dioxide $\left(\mathrm{CO}_{2}\right)$ in the atmosphere causes ocean acidification. Acidification becomes a threat to seagrass. Nowadays, one of the challenges that must be faced is to predict the long-term impact of acidification on the physiology of seagrass. This research aims to analyze seagrass Cymodocea rotundata leave physiology responses to $\mathrm{pH}$ that consists of chlorophyll-a and b content, photosynthesis rate, and growth rate of seagrass leaf. This research was conducted on SeptemberDecember 2017 in Marine Habitat Laboratory, Department of Marine Science and Technology, Bogor Agricultural University. The method used a completed randomized design with five repetitions. $p H$ treatment used in this research is low $\mathrm{pH}$ (7.55), medium $\mathrm{pH}$ (7.78), and control (8.20). The setting of $\mathrm{pH}$ value was done by adding $\mathrm{CO}^{2}{ }^{2}$. Chlorophyll-a and $b$ contents, photosynthesis rate, and growth rate on $C$. rotundata leaf are higher on control $\mathrm{pH}$ treatment than medium $\mathrm{pH}$ (7.78) and low $\mathrm{pH}$ (7.55). ANOVA test shows that only chlorophyll-a is significantly different. The difference $\mathrm{pH}$ affects the chlorophyll content of $a$ and $b$, photosynthesis rate, and leaf growth rate. The low $p H$ of seawater has been shown to inhibit the physiological activity of $C$. rotundata leaves.
\end{abstract}

Keywords: chlorophyll, growth, photosynthesis, seagrass

\begin{abstract}
ABSTRAK
Meningkatnya konsentrasi karbondioksida $\left(\mathrm{CO}_{2}\right)$ di atmosfer dapat menyebabkan asidifikasi laut. Asidifikasi menjadi ancaman bagi lamun. Salah satu tantangan yang harus dihadapi saat ini adalah memprediksi dampak jangka panjang dari asidifikasi laut terhadap fisiologi lamun. Tujuan penelitian ini untuk menganalisis respons fisiologis lamun $C$. rotundata yang meliputi kandungan klorofil a dan b, laju fotosintesis dan laju pertumbuhan daun lamun. Penelitian dilaksanakan pada bulan SeptemberDesember 2017 di Laboratorium Marine Habitat Departemen Ilmu dan Teknologi Kelautan, Institut Pertanian Bogor. Metode yang digunakan adalah rancangan percobaan acak lengkap 5 pengulangan. Perlakuan $\mathrm{pH}$ yang digunakan yaitu pada nilai $\mathrm{pH}$ rendah $(7,55)$, menengah $(7,78)$ dan kontrol $(8,20)$. Pengaturan nilai $\mathrm{pH}$ dengan cara menambahkan unsur $\mathrm{CO}_{3}{ }^{2-}$. Kandungan klorofil a dan $\mathrm{b}$, Laju fotosintesis dan Laju pertumbuhan daun $C$. rotundata perlakuan $\mathrm{pH}$ 8,20 lebih tinggi dibandingkan dengan perlakuan $\mathrm{pH} 7,78$ dan $\mathrm{pH} 7,55$. Uji ANOVA menunjukkan hanya klorofil a yang berbeda signifikan. Perbedaan $\mathrm{pH}$ memengaruhi kandungan klorofil a dan b, laju fotosintesis dan laju pertumbuhan daun. Rendahnya $\mathrm{pH}$ air laut terbukti menghambat aktivitas fisiologis daun lamun $C$. rotundata.
\end{abstract}

Kata kunci: fotosintesis, klorofil, pertumbuhan, seagrass

\section{PENDAHULUAN}

Sumber utama karbondioksida $\left(\mathrm{CO}_{2}\right)$ di atmosfer berasal dari pembakaran bahan bakar fosil seperti minyak, batu bara, dan gas alam (IPCC, 2014). Sejak abad ke-20, tingginya penggunaan bahan bakar fosil memengaruhi laju pertumbuhan karbon-dioksida $\left(\mathrm{CO}_{2}\right)$ beberapa kali lipat (Canadell et al., 2007). IPCC (2013) menjelaskan peningka- 
tan konsentrasi karbondioksida $\left(\mathrm{CO}_{2}\right)$ terlihat sangat signifikan, bahkan lebih cepat dari prediksi sebelumnya. Keadaan ini menyebabkan terjadinya asidifikasi laut (Fabry et al., 2009). pH air laut diperkirakan akan turun 0,3 sampai 0,4 unit, sesuai dengan meningkatnya karbondioksida $\left(\mathrm{CO}_{2}\right)$ antara 300-400 \% (Waldbusser et al., 2011). Menurut IPCC (2014) pembakaran bahan bakar fosil terus berlanjut dalam 100 tahun kedepan, sehingga dapat menyebabkan penurunan $\mathrm{pH}$ permukaan laut hingga mencapai angka 7,5.

$\mathrm{pH}$ air laut berkaitan erat dengan karbon terlarut, semakin banyak karbondioksida $\left(\mathrm{CO}_{2}\right)$ dan asam karbonat $\left(\mathrm{H}_{2} \mathrm{CO}_{3}\right)$, maka $\mathrm{pH}$ akan semakin rendah (Effendi, 2003). Zeebe \& Wolf-Gladrow (2001) menyatakan karbondioksida $\left(\mathrm{CO}_{2}\right)$ berpartisipasi dalam reaksi kesetimbangan sebagai sistem penyangga. Sarmiento \& Gruber (2006) menyatakan dalam proses asidifikasi, karbondioksida $\left(\mathrm{CO}_{2}\right)$ yang ada di atmosfer masuk ke dalam laut dan bereaksi dengan air laut $\left(\mathrm{H}_{2} \mathrm{O}\right)$ kemudian membentuk asam karbonat $\left(\mathrm{H}_{2} \mathrm{CO}_{3}\right)$. Asam karbonat $\left(\mathrm{H}_{2} \mathrm{CO}_{3}\right)$ di perairan akan melepas ion $\mathrm{H}^{+}$dan membentuk bikarbonat $\left(\mathrm{HCO}_{3}^{-}\right)$. Ion bikarbonat $\left(\mathrm{HCO}_{3}{ }^{-}\right)$akan melepas ion $\mathrm{H}^{+}$dan membentuk karbonat $\left(\mathrm{CO}_{3}{ }^{2-}\right)$. Ion $\mathrm{H}^{+}$yang dilepas menyebabkan $\mathrm{pH}$ perairan laut menurun (Mackereth et al., 1989; Sarmiento \& Gruber, 2006).

Tantangan yang harus dihadapi adalah mengurangi dampak dari asidifikasi laut dan bagaimana mempertahankan fungsi dari ekosistem laut (Widdicombe \& Spicer, 2008). Knutzen (1981) menyatakan bahwa biota laut mampu mentolerir penurunan $\mathrm{pH}$ 0,5 sampai 1,0 unit, dalam kondisi $\mathrm{pH}$ yang lebih rendah akan menganggu proses fotosintesis, mengurangi kalsifikasi karang, dan menghambat pertumbuhan organisme. Fabricius et al. (2011) mengungkapkan hal yang berbeda, asidifikasi berdampak pada meningkatnya aktivitas fotosintesis, produktivitas dan biomassa lamun. Ekosistem lamun memegang peranan penting untuk aktivitas perikanan (Bastyan \& Cambridge, 2008). Disamping itu, lamun juga berperan dalam siklus gas karbondioksida yang mampu menyerap gas karbondioksida di atmosfer (Gullstrom et al., 2017). Lamun membutuhkan cukup banyak karbon anorganik untuk pertumbuhan dan kelangsungan hidupnya (Fourqurean et al., 2012). C. rotundata merupakan salah satu spesies yang banyak ditemukan di kawasan Indo-Pasifik (Short et al., 2007).

Beberapa penelitian sebelumnya menunjukkan bahwa asidifikasi laut meningkatkan aktivitas fotosintesis pada spesies $C$. serrulata, Halodule uninervis, Thalasia hemprichii (Ow et al., 2015) dan Zoostera polichlamys (Borum et al., 2016). Asidifikasi laut menghambat aktivitas fotosintesis lamun Zoostera marina (Zimmerman et al., 2017). Asidifikasi laut juga mengubah keseragaman komunitas lamun (Duarte et al., 2013). pH sangat memengaruhi pertumbuhan dan produktivitas dari lamun $C$. rotundata. Belum adanya data mengenai pengaruh dari asidifikasi terhadap fisiologis lamun $C$. rotundata menjadi salah satu dasar untuk dilakukannya penelitian ini. Penelitian ini bertujuan untuk menganalisis respons fisiologis daun lamun $C$. rotundata yang meliputi kandungan klorofil, laju fotosintesis, pertumbuhan daun C. rotundata terhadap pemberian karbonat $\left(\mathrm{CO}_{3}{ }^{2-}\right)$ pada kondisi $\mathrm{pH}$ yang berbeda.

\section{METODE PENELITIAN}

\subsection{Waktu dan Lokasi Penelitian}

Penelitian telah dilaksanakan pada bulan September-Desember 2017. Sampel lamun $C$. rotundata berasal dari Pulau Pari Kepulauan Seribu, Jakarta. Sampel lamun ditransplantasi kembali dalam toples di Laboratorium Marine Habitat, Fakultas Perikanan dan Ilmu Kelautan, IPB University.

\subsection{Alat dan Bahan}

Penelitian menggunakan alat sebagai berikut: $\mathrm{pH}$ meter, termometer, lampu LED 
(Light Emitting Diode), refraktometer, portable photosynthesis system analysis, gelas ukur, kantong sampel, timbangan, penggaris, botol sampel, pipet tetes, sekop, coolbox, kamera, dan alat tulis. Adapun bahan yang digunakan adalah lamun $C$. rotundata, pupuk cair, etanol, air laut, akuades dan $\mathrm{CO}_{3}{ }^{2-}$.

\subsection{Prosedur Analisis Data}

\subsubsection{Pengambilan Sampel}

Tunas lamun $C$. rotundata dan substrat diambil di Pulau Pari Kepulauan Seribu. C. rotundata diambil dengan menggali tunas utuh dengan rimpang terhubung pada sedimen sebelum dipindahkan ke toples. Sampel diambil kemudian dimasukkan ke dalam coolbox dan diaerasi, selanjutnya ditransplantasi ke toples (Riniatsih \& Endrawati, 2013). Komposisi pupuk, karbonat dan lampu disesuaikan dengan hasil penelitian pendahuluan yang dilakukan selama 1 bulan di Laboratorium Marine Habitat, Fakultas Perikanan dan Ilmu Kelautan, Institut Pertanian Bogor.

\subsubsection{Rancangan Penelitian}

Toples digunakan sebagai wadah untuk menumbuhkan lamun. Rancangan penelitian menggunakan rancangan acak lengkap dengan menggunakan tabel acak (Figure 1). Sebanyak lima belas toples digunakan untuk 3 perlakuan dengan 5 pengulangan. Perlakuan $\mathrm{pH}$ yang digunakan mengacu pada data IPCC (2014), untuk kontrol $(8,20)$ merupakan kondisi $\mathrm{pH}$ laut saat ini, dalam perlakuan $\mathrm{pH}$ sedang $(7,78)$ merupakan kondisi $\mathrm{pH}$ laut 50 tahun yang akan datang, sedangkan untuk $\mathrm{pH}$ rendah $(7,55)$ merupakan kondisi pH laut 100 tahun yang akan datang. Setiap toples diisi air laut sebanyak $1,5 \mathrm{~L}$ dan satu tunas lamun $C$. rotundata. Pengaturan $\mathrm{pH}$ dilakukan dengan menambahkan karbonat $\left(\mathrm{CO}_{3}{ }^{2-}\right)$. Pencahayaan menggunakan lampu LED 12 watt yang dipasang $30 \mathrm{~cm}$ di atas permukaan toples setiap 12 jam dalam satu hari. Pergantian air dilakukan setiap 2 minggu sekali, sedangkan untuk pemberian pupuk dilakukan setiap 1 minggu sebanyak $1,5 \mathrm{~mL}$.

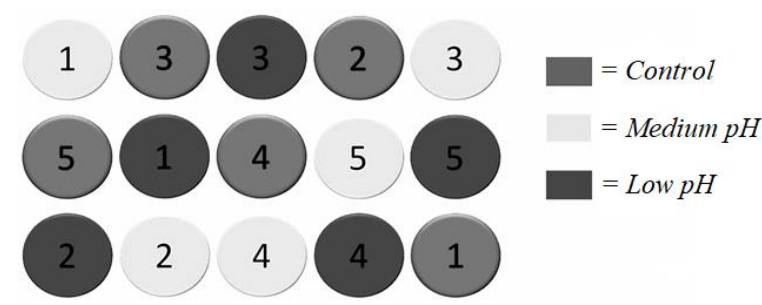

Figure 1. Research design.

\subsubsection{Kandungan Klorofil}

Berdasarkan Granger \& Izumi (2002) penentuan konsentrasi klorofil diketahui dengan mengukur ekstrak daun lamun. Setiap sampel absorbansi menggunakan panjang gelombang $664 \mathrm{~nm}$ dan $647 \mathrm{~nm}$. Kandungan klorofil lamun $C$. rotundata dihitung dengan rumus:

Klorofil $a=$

$$
11,93 \text { E664-1,93 E647 }
$$

Klorofil $b=$

$$
20,36 \text { E647-4,68 E647 }
$$

Keterangan: $E_{664}$ adalah gelombang absorbansi, $E_{647}$ adalah gelombang absorbansi.

\subsubsection{Laju Fotosintesis}

Laju fotosintesis diukur menggunakan Portable photosynthesis system analysis (LI-COR model LI-6400) dengan penyuntik $\mathrm{CO}_{2}$ dan sumber cahaya LED. Data pengamatan dianalisis dengan pengaturan program berupa kurva respon intensitas cahaya (PAR = Photosynthesis Active Radition) dari 1$1200 \mu \mathrm{mol} \mathrm{CO} \mathrm{m}^{-2} \mathrm{~s}^{-1}$ (Soleh, 2017).

\subsubsection{Laju Pertumbuhan}

Pengukuran laju pertumbuhan daun lamun $C$. rotundata mengacu pada Short \& Duarte (2001). Pertumbuhan daun lamun $C$. rotundata dihitung dengan rumus:

$P=\frac{P t-P 0}{\Delta t}$ 
Keterangan: $P$ adalah pertumbuhan daun lamun $C$. rotundata ( $\mathrm{mm} / \mathrm{hari}), P t$ adalah panjang daun akhir $(\mathrm{mm}), P 0$ adalah panjang daun awal $(\mathrm{mm}), \Delta t$ adalah lama waktu pengamatan (hari).

\subsubsection{Kualitas Perairan}

Parameter kualitas air yang diukur meliputi suhu menggunakan termometer dan salinitas dengan menggunakan refraktometer (APHA, 2012).

\subsubsection{Analisis Statistik}

Analisis data menggunakan ANOVA one way pada taraf nyata $5 \%$ pada Microsoft Excel untuk menentukan perbedaan dari kandungan klorofil, laju fotosintesis, dan laju pertumbuhan daun lamun $C$. rotundata (Suliyanto, 2012).

\section{HASIL DAN PEMBAHASAN}

\subsection{Hasil}

\subsubsection{Kualitas Perairan}

Kualitas air yang diamati secara in situ pada perlakuan $\mathrm{pH}$ rendah, sedang dan kontrol (Table 1). Nilai rata-rata suhu berkisar antara $26,58^{\circ} \mathrm{C}-26,61^{\circ} \mathrm{C}$. Suhu tertinggi dijumpai pada perlakuan $\mathrm{pH}$ sedang, dan suhu terendah pada perlakuan $\mathrm{pH}$ kontrol. Nilai rata-rata salinitas pada penelitian ini berkisar antara 33,26 psu-33,33 psu.

\subsubsection{Kandungan Klorofil $C$. rotundata}

Hasil pengukuran kandungan klorofil a dan b $C$. rotundata (Figure 2) perlakuan $\mathrm{pH}$ kontrol $(8,20)$ sebesar $1,77 \mathrm{mg} / \mathrm{g}$ dan $1,43 \mathrm{mg} / \mathrm{g}$ berada pada kisaran 1,62-1,97 $\mathrm{mg} / \mathrm{g}$ (klorofil a) dan 1,21-1,94 $\mathrm{mg} / \mathrm{g}$ (klorofil b). Kandungan klorofil a dan b $C$. rotundata perlakuan $\mathrm{pH}$ 7,78 sebesar 1,56 $\mathrm{mg} / \mathrm{g}$ dan $\mathrm{mg} / \mathrm{g} 1,24$ berada pada kisaran 0$2,60 \mathrm{mg} / \mathrm{g}$ (klorofil a) dan $0-1,94 \mathrm{mg} / \mathrm{g}$ (klorofil b). Kandungan klorofil a dan b $C$. rotundata perlakuan $\mathrm{pH} 7,55$ sebesar 0,58 $\mathrm{mg} / \mathrm{g}$ dan $0,59 \mathrm{mg} / \mathrm{g}$ berada pada kisaran 0 $1,83 \mathrm{mg} / \mathrm{g}$ (klorofil a) dan $0-1,44 \mathrm{mg} / \mathrm{g}$ (klorofil b). Hasil uji ANOVA menunjukkan rata-rata hasil kandungan klorofil a pada daun lamun berbeda signifikan $(\mathrm{P}<0,05)$

Table 1. The value range of physical and chemical parameters of water quality.

\begin{tabular}{lccc}
\hline \multirow{2}{*}{ Water quality } & \multicolumn{3}{c}{$p H$ treatments } \\
\cline { 2 - 4 } & $\mathrm{L}(7.55)$ & $\mathrm{M}(7.78)$ & $\mathrm{C}(8.20)$ \\
\hline Temperature $\left({ }^{\circ} \mathrm{C}\right)$ & $26.60 \pm 0.41$ & $26.61 \pm 0.42$ & $26.58 \pm 0.42$ \\
Salinity $(\mathrm{psu})$ & $33.27 \pm 2.08$ & $33.33 \pm 2.12$ & $33.26 \pm 2.06$ \\
\hline
\end{tabular}

Information: The values are presented as mean \pm standard deviation. $L=$ low $p H, M=$ medium $\mathrm{pH}, \mathrm{C}=$ control.

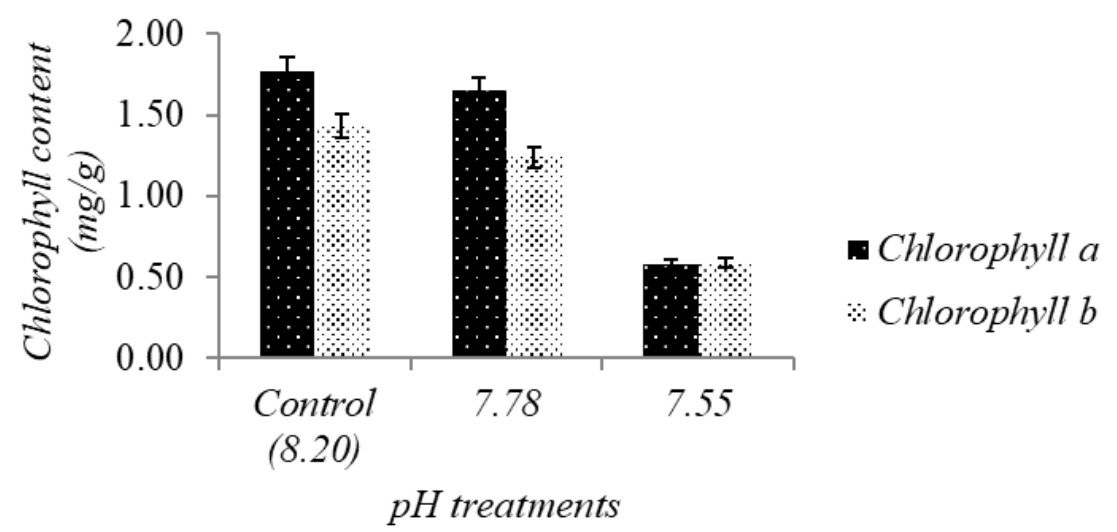

Figure 2. The average hlorophyll content of $C$. rotundata. 
dan rata-rata hasil kandungan klorofil b pada daun lamun tidak berbeda signifikan $(\mathrm{P}>$ $0,05)$.

\subsubsection{Laju Fotosintesis C. rotundata}

Hasil pengukuran laju fotosintesis lamun $C$. rotundata (Figure 3) pada perlakuan $\mathrm{pH}$ kontrol $(8,20)$ sebesar 8,89 $\mu \mathrm{mol} \mathrm{CO} \mathrm{Cm}^{-2} \mathrm{~s}^{-1}$ berada pada kisaran 6,59$11,45 \mu \mathrm{mol} \mathrm{CO} \mathrm{Cm}^{-2} \mathrm{~s}^{-1}$. Laju fotosintesis $C$. rotundata pada perlakuan $\mathrm{pH} 7,78$ sebesar $6,85 \mu \mathrm{mol} \mathrm{CO}_{2} \mathrm{~m}^{-2} \mathrm{~s}^{-1}$ berada pada kisaran 5,51-8,36 $\mu$ mol $\mathrm{CO}_{2} \quad \mathrm{~m}^{-2} \quad \mathrm{~s}^{-1}$. Laju fotosintesis $C$. rotundata pada perlakuan $\mathrm{pH}$ 7,55 sebesar $6,87 \mu \mathrm{mol} \mathrm{CO}_{2} \mathrm{~m}^{-2} \mathrm{~s}^{-1}$ berada pada kisaran $0-13,20 \mu \mathrm{mol} \quad \mathrm{CO}_{2} \quad \mathrm{~m}^{-2} \mathrm{~s}^{-1}$. Hasil uji ANOVA menunjukkan rata-rata hasil laju fotosintesis $C$. rotundata tidak signifikan $(\mathrm{P}>0.05)$.

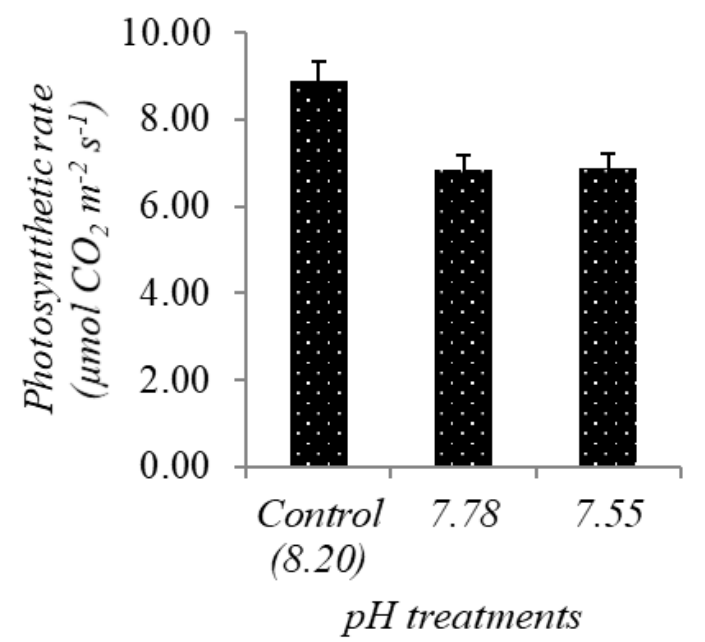

Figure 3. The average photosynthetic rate of C. rotundata.

\subsubsection{Laju Pertumbuhan Daun $C$. rotundata}

Berdasarkan data laju pertumbuhan daun $C$. rotundata (Figure 4) pada perlakuan $\mathrm{pH}$ kontrol $(8,20)$ memiliki laju pertumbuhan daun $C$. rotundata sebesar $2,74 \mathrm{~mm} / \mathrm{hari}$ yang berada pada kisaran 1,00-5,56 $\mathrm{mm} /$ hari. Laju pertumbuhan daun $C$. rotundata pada perlakuan $\mathrm{pH} 7,78$ sebesar 2,51 $\mathrm{mm} /$ hari yang berada pada kisaran 1,53-3,56 $\mathrm{mm} /$ hari. Laju pertumbuhan pada
$\mathrm{pH} 7,75$ sebesar $1,72 \mathrm{~mm} /$ hari yang berada pada kisaran $0,70-2,50 \mathrm{~mm} /$ hari. Hasil uji ANOVA pertumbuhan daun $C$. rotundata menunjukkan rata-rata hasil tidak signifikan $(\mathrm{P}>0,05)$.

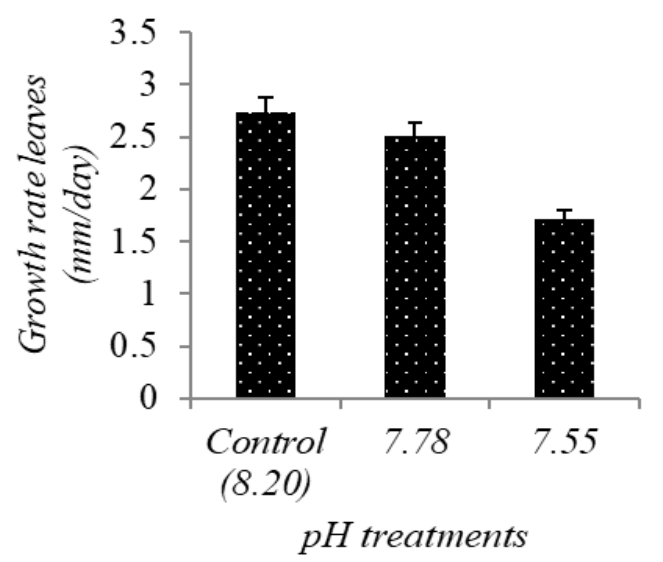

Figure 4. The average growth rate leaves of C. rotundata.

\subsection{Pembahasan}

Karbonat dimasukkan ke dalam perlakuan pH 7,55 dan pH 7,78 bereaksi dengan kalsium (Ca) menjadi kalsium karbonat $\left(\mathrm{CaCO}_{3}\right)$. Hal ini terlihat adanya butiranbutiran kapur pada kolom air. Nontji (1993) menyatakan bahwa pada dasarnya $\mathrm{pH}$ air laut akan kembali pada nilai semula karena adanya sistem karbondioksida yang berfungsi sebagai penyangga. Selama satu bulan pengamatan suhu tidak terjadi perubahan nilai yang signifikan. Nilai suhu yang didapatkan tergolong rendah dan masih dalam kisaran suhu optimal untuk pertumbuhan lamun, hal ini disebabkan pada bulan November-Desember termasuk ke dalam musim hujan. Menurut Effendi (2003) salah satu faktor yang memengaruhi suhu air laut adalah musim. Pengukuran salinitas selama satu bulan tidak terjadi peningkatan atau penurunan signifikan, hal ini disebabkan tidak adanya aktivitas percampuran dengan air tawar. Kisaran nilai salinitas yang didapat masih dalam nilai optimum untuk kehidupan lamun. Salinitas optimal untuk pertumbuhan lamun berkisar antara 25-35 psu (Supriharyono, 2009). 
Selama satu bulan pengamatan ditemukan pada perlakuan $\mathrm{pH} 7,55$ ada sebanyak 4 daun yang gugur, pada perlakuan $\mathrm{pH} 7,78$ ada sebanyak 5 daun dan pada perlakuan kontrol $(8,20)$ hanya 2 daun yang gugur selama satu bulan. Lambers et al. (1998) menyebutkan bahwa lamun merespons perubahan lingkungan hingga pada kondisi stres. Kondisi stres terjadi pada hitungan hari hingga bulan. $\mathrm{pH}$ merupakan salah satu faktor yang menjadi penyebab hilangnya klorofil pada daun tumbuhan. Asidifikasi berdampak pada hilangnya unsur magnesium $(\mathrm{Mg})$, sehingga akan terjadi perubahan warna pada daun. Pigmen klorofil yang berwarna hijau akan membentuk pigmen pheophityn yang berwarna cokelat. Fennema (1996) menambahkan pada media asam $(\mathrm{pH}<8)$ klorofil tidak stabil, penurunan $\mathrm{pH}$ pada air laut yang terjadi ketika pemanasan jaringan daun mengakibatkan hilangnya pigmen klorofil.

Aktivitas fotosintesis lamun $C$. rotundata dipengaruhi oleh klorofil sebagai penyerap cahaya. Daya serap sinar lampu yang rendah pada fotosintesis dipengaruhi oleh kandungan klorofil-a dan $b$ pada perlakuan $\mathrm{pH}$ 7,55 klorofil-a dan b memiliki nilai yang rendah, sehingga berdampak pada laju fotosintesis yang rendah. Berbeda dengan pada perlakuan $\mathrm{pH} \quad 7,78$ yang memiliki nilai klorofil-a dan b cukup tinggi, namun laju fotosintesisnya rendah diduga daun muda yang baru tumbuh memiliki daya serap $\mathrm{CO}_{2}$ yang kecil. Perlakuan $\mathrm{pH}$ kontrol $(8,20)$ klorofil-a dan b memiliki nilai yang tinggi, sehingga berdampak pada laju fotosintesis yang tinggi. Ketersediaan karbondioksida $\left(\mathrm{CO}_{2}\right)$ dalam air laut memengaruhi aktivitas fotosintesis lamun $C$. rotundata (Lambers et al., 1998). Laju fotosintesis lamun tergantung pada difusi karbon melalui kutikula pada permukaan daun (Kawaroe et al., 2016). Lamun memperoleh karbondioksida $\left(\mathrm{CO}_{2}\right)$ dari air laut yang memiliki konsentrasi karbon anorganik tinggi (Hein \& Sand-Jensen, 1997).
Secara tidak langsung perbedaan $\mathrm{pH}$ air laut memengaruhi pertumbuhan daun lamun $C$. Rotundata, tingginya nilai pertumbuhan daun lamun berbanding lurus dengan nilai kandungan klorofil dan nilai laju fotosintesis. Penelitian menunjukkan pada perlakuan $\mathrm{pH} 7,55$ saat lamun sudah tumbuh pada ukuran $\pm 5 \mathrm{~cm}$ beberapa daun terlihat menguning. Hal ini mengindikasikan bahwa kandungan klorofil lamun sudah hilang, sehingga daun lamun tersebut tidak dapat tumbuh lagi. Banyak faktor dapat memengaruhi pertumbuhan lamun (Dunton, 1994). Pertumbuhan daun lamun dipengaruhi oleh faktor fisiologis, metabolisme, lingkungan (Azkab \& Kiswara, 1994) dan nutrien (Lee \& Dunton, 2000). Vonk et al. (2015) menyatakan bahwa ukuran tubuh lamun juga memengaruhi pertumbuhan lamun. Lamun C. rotunda memiliki ukuran tubuh dan luas penampang daun yang kecil, sehingga memiliki daya serap yang kecil.

\section{KESIMPULAN}

Perbedaan $\mathrm{pH}$ air laut memengaruhi kandungan klorofil-a dan b, laju fotosintesis dan laju pertumbuhan daun. Kandungan klorofil-a dan b, laju fotosintesis dan laju pertumbuhan daun lamun $C$. rotundata perlakuan $\mathrm{pH}$ kontrol lebih besar dibandingkan dengan perlakuan $\mathrm{pH} 7,78$ dan $\mathrm{pH} 7,55$. Uji ANOVA menunjukkan hanya klorofil-a yang berbeda signifikan. Rendahnya $\mathrm{pH}$ air laut terbukti menghambat aktivitas fisiologis daun lamun $C$. rotundata.

\section{UCAPAN TERIMA KASIH}

Penulis mengucapkan terima kasih kepada Ibu Dr. Mujizat Kawaroe dan Ibu Dr. Neviaty P. Zamani yang telah membantu mendanai dan memfasilitasi kegiatan riset serta semua pihak yang telah berkontribusi selama kegiatan berlangsung. 


\section{DAFTAR PUSTAKA}

American Public Health Association (APHA). 2012. Standar method for the examination of water and waste wayer. 22 Edition. Environmental Protection Agency Press. Washington DC. 1360 p.

Azkab, M.H. \& W. Kiswara. 1994. Struktur komunitas biologi padang lamun di pantai selatan lombok dan kondisi lingkungannya. Pusat Penelitian dan Pengembangan Oseanologi LIPI. Jakarta. 124 p.

Bastyan, G.R. \& M.L. Cambridge. 2008. Transplantation as a method for restoring the seagrass Posidonia australis. Estuarine, Coastal and Shelf Science, 79: 289-299.

https://doi.org/10.1016/j.ecss.2008.04 .012

Borum, J., O. Pederson, L. Kotulo, M.W. Fraser, J. Statton, T.D. Colmer, \& G.A. Kendrick. 2016. Photosynthetic response to globally increasing $\mathrm{CO}_{2}$ of co-occuring temperate seagrass species. Plant, Cell and Environment, 39: 1240-1250.

https://doi.org/10.1111/pce.12658

Canadell, J.P., C. Le Quere, M.R. Raupach, C.B. Field, E.T. Buitenhuis, P. Ciais, T.J. Conway, N.P. Gillett, R.A. Houghton, \& G. Marland. 2007. Contributions to accelerating atmospheric $\mathrm{CO}_{2}$ growth from economic activity, carbon intensity, and efficiency of natural sinks. Proc Natl Acad Sci, 104(47): 1886618870.

https://doi.org/10.1073/pnas.0702737 104

Duarte, C.M., I.E. Hendriks, T.S. Moore, Y.S. Olsen, A. Steckbauer, L. Ramajo, J. Carstensen, J.A. Trotter, \& M. Mcculloch. 2013. Is ocean acidification an open-ocean syndrome? Understanding anthropogenic impacts on seawater
pH. Estuarine and Coastal, 36: 221-

236. https://doi.org/10.1007/s12237013-9594-3

Dunton, K.H. 1994. Seasonal growth and biomass of the subtropical seagrass Halodule wrightii in relation to continuous measurements of underwater irradiance. Marine Biology, 120: 479-489. https://doi.org/10.1007/BF00680223

Effendi, H. 2003. Telaah Kualitas Air Bagi Pengelolaan Sumberdaya dan Lingkungan Perairan. Kanisius. Yogyakarta. $256 \mathrm{p}$.

Fabricius, K.E., C. Langdon, S. Uthicke, C. Humphrey, S. Noonan, G. De'ath, R. Okazaki, N. Muehllehner, M.S. Glas, \& J.M. Lough. 2011. Losers and winners in coral reefs acclimatized to elevated carbon dioxide concentrations. Nature Climate Change, 1: 165-169. https://doi.org/10.1038/nclimate1122

Fabry, V.J., J.B. McClintock, J.T. Mathis, \& J.M. Grebmeier. 2009. Ocean acidification at high latitudes: The Bellwether. Oceanography, 22(4): 160-171.

https://doi.org/10.5670/oceanog.2009 .105

Fennema. 1996. Food Chemitry 3 th edition. Marcel Dekker. Inc New York. 1067 p.

Fourqurean, J.W., C.M. Duarte, H. Kennedy, \& M. Marbà. 2012. Seagrass ecosystems as a globally significant carbon stock. Nature Geoscience, 1: 1-5. https://doi.org/10.1038/ngeo1477

Granger, S. \& H. Izumi. 2002. Water quality measurement methods for seagrass habitats. Elsevier Science, 20: 393405. https://doi.org/10.1016/B978044450891-1/50021-9

Gullstrom M., L.D. Lyimo, M. Dahl, G.S. Samuelsson, M. Eggertsen, E. Enderberg, L.M. Rasmusson, H.W. Linderholm, A. Knudby, S. Bandeira, 
L.M Nordlund, \& M. Bjork. 2017. Blue Carbon Storage in Tropical Seagrass Meadows Relates to Carbonate Stock Dynamics, PlantSediment Processes, and Landscape Context: Insights from the Western Indian Ocean. Springer Nature, 21: 551-566.

https://doi.org/10.1007/s10021-0170170-8

Hein, M. \& K. Sand-Jansen. 1997. $\mathrm{CO}_{2}$ Increases oceanic primary production. Nature, 388: 526-527. https://doi.org/10.1038/41457

Intergovernmental Panel on Climate Change (IPCC). 2013. Climate Change 2013: The Physical Science Basis. Contribution of Working Group I to The Fifth Assessment Report of The Intergovernmental Panel on Climate Change. Cambridge University Press. Cambridge. 1585 p.

Intergovernmental Panel on Climate Change (IPCC). 2014. Climate Change 2014: Mitigation of Climate Change. Contribution of Working Group III to the Fifth Assessment Report of the Intergovernmental Panel on Climate Change. Cambridge University Press. Cambridge. $1434 \mathrm{p}$.

Knutzen, J. 1981. Effects of decreased pH on marine organisms. Marine Pollution Bulletin, 12: 25-29. https://doi.org/10.1016/0025326X(81)90136-3

Lambers, H, F.S. Chapin, \& T.L. Pons. 1998. Plant physiological ecology. Springer. New York. 605 p.

Lee, K.S. \& K.H. Dunton. 2000. Effects of nitrogen enrichment on biomass allocation, growth, and leaf morphology of the seagrass Thalassia testudinum. Marine Ecology Progress, 196: 39-48. https://doi.org/10.3354/meps196039

Mackereth, F.J.H., J. Heron, \& J.F. Tailing. 1989. Water analysis. freshwater biological association. Liverpool
University Press. Liverpool. 456-456 p.

Nontji, A. 1993. Laut nusantara. Djambatan. Jakarta. 368 p.

Ow, Y.X., C.J. Collier, \& S. Uthicke. 2015. Response of three tropical seagrass species to $\mathrm{CO}_{2}$ enrichment. Marine Biology, 162: 1005-1007. https://doi.org/10.1007/s00227-0152644-6

Riniatsih I. \& H. Endrawati. 2013. Pertumbuhan lamun hasil transplantasi jenis Cymodocea rotundata di padang lamun teluk awur jepara. Buletin Oseanografi Marina, 2: 34-40.

https://doi.org/10.14710/buloma.v2i1. 6924

Sarmiento, J.L. \& N. Gruber. 2006. Ocean biogeochemical dynamics. Princeton University Press. New Jersey. 503 p.

Short, F.T. \& C.M. Duarte. 2001. Methods for the measurement of seagrass and growth production. di dalam: Short FT, Coles RG, editor. Global seagrass research methods. Elsevier Science, 8: $155-182$.

https://doi.org/10.1016/B978044450891-1/50009-8

Short, F.T., T. Carruters, W. Dennison, \& M. Waycott. 2007. Global seagrass distribution and diversity: a bioregion model. J. of Experimental Marine Biology and Ecology, 350: 3-20. https://doi.org/10.1016/j.jembe.2007. 06.012

Soleh, M.A. 2017. Overestimation measurement of gas exchange by using Portable Photosynthesis Analyzer LI-6400. J. Kultivasi, 16(1): 255-259.

https://doi.org/10.24198/kltv.v16i1.1 1546

Suliyanto. 2012. Analisis statistik pendekatan praktis dengan Microsoft excel. Andi offset. Yogyakarta. 232 p. 
Supriharyono. 2009. Konservasi ekosistem sumberdaya hayati. Pustaka Pelajar. Yogyakarta. $428 \mathrm{p}$.

Vonk, J.A., M.J.A. Christianen, J. Stapel, \& K.R. O'Brien. 2015. What lies beneath: why knowledge of belowground biomass dynamic is crusial to effective seagrass management. Ecological Indicators, 57: 259-267. https://doi.org/10.1016/j.ecolind.2015 .05 .008

Waldbusser, G.G., E.P. Voigt, H. Bergschneider, M.A. Green, \& R.I. Newell. 2011. Biocalcification in the eastern oyster (Crassostrea virginica) in relation to long-term trends in Chesapeake Bay $\mathrm{pH}$. Estuaries and Coasts, 34(2): 221-231. http://doi.org/10.1007/s12237-0109307-0

Widdicombe, S. \& J.I. Spicer. 2008. Predicting the impact of ocean acidification on benthic diversity. What can animal physiology tell us?, J. Experimental Marine Biolology Ecology, 366: 187-197.

https://doi.org/10.1016/j.jembe.2008. 07.024

Zeebe, R.E. \& D. Wolf-Gladrow. 2001. $\mathrm{CO}_{2}$ in seawater: equilibrium, kinetics, isotopes. Elsevier Science. Netherlands. $360 \mathrm{p}$.

Zimmerman, R.C., V.J. Hill, M. Jinuntuya, B. Celebi, D. Ruble, M. Smith, T. Cedeno, \& W.M. Swingle. 2017. Experimental impacts of climate warming and ocean carbonation on eelgrass Zoostera marina. Marine Ecology Progress Series, 566: 1-15. https://doi.org/10.3354/meps12051

Received : 6 July 2018

Reviewed : 27 February 2019

Accepted : 18 August 2020 
